\title{
Keeping it Clean: Cleaning Bathrooms, Sink, Bathtub, Shower, Toilet 1
}

Mary N. Harrison ${ }^{2}$

Every family member can help keep the bathroom clean and in good condition. Some chores need to be done daily, others weekly.

\section{Supplies Needed}

- Liquid chlorine laundry bleach

- Rubber gloves

- Rags or a sponge

- An old toothbrush or wooden scraper

- Dishwashing detergent

- A scrub brush

- Baking soda or abrasive cleanser

- Toilet bowl brush

- Bucket

\section{To Clean the Bathroom Sink}

\section{Daily}

1. Rinse out the sink after each use.

2. Rinse off the bar of soap after you use it. (Don't leave a dirty bar of soap in the soap dish.)

3. Turn off the faucets completely.

\section{Weekly}

1. Wet a rag or sponge. Sprinkle lightly with the baking soda or abrasive cleanser, then scrub the sink.

2. Dried-on soap or toothpaste can be removed with a scraper or toothbrush. Then scrub counters with a rag or sponge dampened with detergent and water.

3. Mix one or two capfuls of chlorine bleach in a gallon of warm water.

4. Rinse your rag often in this mixture as you wipe to clean the counters. This step will clean away soil and prevent the spread of harmful bacteria.

1. This document is FCS5232-04, one of a series of the Family Youth and Community Sciences Department, Florida Cooperative Extension Service, Institute of Food and Agricultural Sciences, University of Florida. Original publication date June 2002. Revised December 2005. Visit the EDIS Web Site at http://edis.ifas.ufl.edu.

2. Mary N. Harrison, professor, Department of Family, Youth and Community Sciences, Cooperative Extension Service, Institute of Food and Agricultural Sciences, University of Florida, Gainesville, 32611.

The Institute of Food and Agricultural Sciences (IFAS) is an Equal Opportunity Institution authorized to provide research, educational information and other services only to individuals and institutions that function with non-discrimination with respect to race, creed, color, religion, age, disability, sex, sexual orientation, marital status, national origin, political opinions or affiliations. U.S. Department of Agriculture, Cooperative Extension Service, University of Florida, IFAS, Florida A. \& M. University Cooperative Extension Program, and Boards of County Commissioners Cooperating. Larry Arrington, Dean 


\section{To Clean the Bathtub}

\section{Daily}

1. Wash out the bathtub after each use and remove any hair left in the drain.

2. Turn off the faucets completely.

3. Hang bath towels and washcloths to dry.

4. Put dirty clothes in the laundry basket. Make sure they are dry before putting in the laundry basket.

\section{Weekly}

1. Remove hair from the drain. Some bathtubs have lever closures for the tub drain. (The drain is opened and closed by turning the lever). To clean, lift the cover from the tub drain. Clean the hair and soap scum. Rinse, then replace the cover.

2. Wet a rag or sponge with water and sprinkle lightly with baking soda or a cleanser. Scrub the tub surfaces. Rinse with cold water.

3. To remove mildew, scrub with a mixture of $1 / 4$ cup liquid chlorine bleach in a gallon of water.

4. If the caulk around the edge of the tub is crumbled or broken, remove it carefully with a scraper. Clean and dry. Squeeze new caulk into the crack between the tub and wall. Let it dry overnight before using the tub or shower.

\section{To Clean the Shower}

\section{Daily}

1. After taking a shower, wipe the walls with a towel to remove moisture. This helps prevent mildew and soap scum buildup.

2. Pull the shower curtain so that it is spread the length of the tub and will dry completely.

\section{To Clean the Toilet}

Never put anything in a toilet except toilet paper. Other items will clog the toilet.
1. Measure 1/2 cup bleach into the toilet. Let soak for 10 minutes. Scrub the inside of the toilet bowl with a toilet bowl brush.

2. Scrub under the rim and along the water line to remove the minerals left by the water. Never use the brush for anything else.

3. Mix two capfuls of bleach in a gallon of water.

4. Use this bleach water and a rag to scrub the lid, seat and the outside of the toilet. Rinse your rag often in the bleach water. It is a good idea to also scrub the floor and especially right around the toilet. That controls mildew and cleans, too.

Warning! NEVER combine cleaning products. Mixing ammonia and chlorine bleach or other cleaners can make poisonous fumes that can be deadly. 